\title{
Intoxicație acută severă cu metformin la 0 adolescentă - prezentare de caz
}

\author{
Dana Adriana Dăsculțu, Elena Mădălina Petran \\ Spitalul Clinic de Urgență pentru Copii „Grigore Alexandrescu“, București, România
}

\begin{abstract}
REZUMAT
Introducere. Frecvenţa intoxicației acute cu metformin este în creștere odată cu creșterea disponibilității și accesibilității copiilor și adolescenților la acest antidiabetic oral. Evoluția intoxicației cu metformin la copii poate fi severă prin posibilitatea complicării ei cu disfuncții de organ.

Prezentare de caz. Adolescentă, de 16 ani, a fost internată de urgență în clinica de Toxicologie şi Terapie Intensivă a Spitalului Clinic de Urgenţă pentru Copii „Grigore Alexandrescu“ din Bucureşti, prin transfer dintr-o altă unitate medicală, pentru somnolență şi vărsături apărute după ingestia acută voluntară a 10 comprimate de Siofor (Metformin) comprimate a $1.000 \mathrm{mg}$. Examenele paraclinice la internare au decelat prezența acidozei metabolice $(\mathrm{pH}=$ 7,28, $\mathrm{EB}=-9,4 \mathrm{mmol} / \mathrm{l}, \mathrm{HCO} 3=14,2 \mathrm{mmol} / \mathrm{l}$, lactat= $3,5 \mathrm{mmol} / \mathrm{l})$, iar probele funcționale renale au evidenţiat o valoare crescută a creatininei sangvine de $1,57 \mathrm{mg} / \mathrm{dl}$. Pe parcursul admisiei, au fost administrate bicarbonat de sodiu și perfuzii cu glucoză şi electroliți, care nu au dus la normalizarea valorilor echilibrului acido-bazic şi a lactatului, iar evoluția pacientei a fost către alterarea statusului neurologic, dezvoltarea acidozei lactice severe $(\mathrm{pH}=7,19$, lactat $=5,5 \mathrm{mg} / \mathrm{dl}, \mathrm{HCO} 3=18 \mathrm{mmol} / \mathrm{l}$ ) şi a insuficienței renale acute (uree $=59 \mathrm{mg} / \mathrm{dl}$, creatinină $=4,06 \mathrm{mg} / \mathrm{dl}$ ). A fost luată decizia inițierii terapiei de epurare extrarenală şi a fost transferată în secţia de nefrologie a unei alte unități spitalicești. A fost necesară efectuarea a două şedinţe de hemodializă şi s-a obținut normalizarea indicatorilor funcției renale cu „restitutio ad integrum“ a stării de sănătate.

Concluzii. Intoxicația acută cu metformin poate avea o evoluţie gravă, putând conduce către deces dacă nu este recunoscută, monitorizată și tratată cât mai rapid. Evoluția către acidoză lactică impune instituirea rapidă a măsurilor terapeutice suportive sau de epurare extrarenală din cauza potențialului letal.
\end{abstract}

Cuvinte cheie: metformin, intoxicaţie acută, adolescent, acidoză lactică, hemodializă

\section{INTRODUCERE}

Intoxicațiile acute la copil şi adolescent sunt în continuă creștere, studiile cuantificând că acestea reprezintă aproximativ $20 \%$ dintre internările de urgență în ţările în curs de dezvoltare. În România, intoxicațiile acute la copil reprezintă aproximativ $10 \%$ dintre accidentele din viața curentă. Medicamentele, ca etiologie a intoxicațiilor acute la copil şi adolescent, ocupă o proporție semnificativă (1).

Metforminul este un antidiabetic oral din clasa biguanide, utilizat ca primă linie de terapie în diabetul zaharat tip 2. Farmacodinamic, metforminul este o moleculă hidrosolubilă ce se absoarbe la nivelul intestinului subțire după administrare, ce este rapid distribuit fără a se lega de proeteinele plasmatice. Timpul de înjumătăţire este de 4-8,7 ore, nu suferă biotransformări la nivel hepatic și nu se elimină biliar, clearance-ul fiind dependent de eliminarea pe cale renală. Mecanismele de acțiune ale metforminului sunt: de inhibare a gluconeogenezei hepatice, de creștere a utilizării glucozei de către țesuturile periferice şi de scădere a absorbției glucozei la nivel gastrointestinal, toate aceste avînd ca finalitate scăderea nivelului sangvin al glucozei (2).

Simptomele asociate intoxicației acute cu metformin sunt predominat gastrointestinale: greaţă, vărsături şi dureri abdominale (3). În cazurile severe, intoxicația acută cu acest antidiabetic oral poate conduce la dezvoltarea acidozei lactice, asociată cu insuficiență renală şi hepatică. Mecanismul apariţiei acidozei lactice nu este pe deplin elucidat, unele studii arătând că metforminul interferă cu funcționalitatea complexului I al lanţului respirator mitocondrial (4). Metforminul activează AMP-protein-kinaza(AMPK), considerată a fi un indicator ce monitorizează încărcarea energetică sistemică și celulară. AMPK este o proteină heterotrimerică alcătuită dintr-o subunitate alfa catalitică și două subunităţi reglatoare beta și gama. Activarea AMPK determină modificarea statusului 
metabolic celular din anabolism în catabolism, sistând căile de consum ATP și restabilind echilibrul energetic. Acidoza lactică este definită ca o acidoză metabolică cu gap anionic mare și o valoare a lactatului mai mare de $5 \mathrm{mmol} / \mathrm{l}$. Hiperlactacidemia este o particularitate frecvent întâlnită în cazul pacienților cu tipuri variate de intoxicații și este parametru utilizat în evaluarea severităţii evoluției acestor pacienţi (5).

Vom prezenta cazul unei adolescente cu intoxicație severă cu metformin dată fiind frecvența crescută a acestui tip de intoxicație la această grupă de vârstă.

\section{PREZENTAREA CAZULUI}

Adolescentă în vârstă de 16 ani şi 10 luni a fost internată de urgenţă în clinica de Toxicologie şi Terapie Intensivă a Spitalului Clinic de Urgenţă pentru Copii „Grigore Alexandrescu“ din Bucureşti, prin transfer dintr-o altă unitate medicală, pentru somnolență şi vărsături apărute după ingestia acută voluntară a 10 comprimate de Siofor (Metformin), comprimate a $1.000 \mathrm{mg}$, cu aproximativ 12 ore anterior. Din anamneză, reţinem că debutul manifestărilor s-a produs la aproximativ 4 ore postingestie cu vărsături, motiv pentru care a fost transportată la cea mai apropiată unitate spitalicească, unde s-a practicat lavaj gastric, s-a administrat cărbune activat și perfuzie de echilibrare electrolitică şi a fost trimisă cu ambulanţa în clinica noastră. Tot din anamneză, am reţinut că adolescenta nu suferea de boli cronice şi nu se afla în tratament cronic medicamentos.

La prezentarea în clinica noastră, pacienta prezenta stare generală moderat alterată, era afebrilă, somnolentă, şi cu extermități reci, saturația în oxigen în aerul atmosferic 98\% murmur vezicular prezent bilateral, fără raluri, $\mathrm{AV}=90 \mathrm{bpm}, \mathrm{TA}=121 / 84 \mathrm{mmHg}$, vărsături incoercibile, abdomen suplu, mobil cu respirația, nedureros spontan şi la palpare, diureză prezentă. Examenul neurologic a arătat o pacientă conștientă, reactivă, cu pupile egale intermediare reactive la stimuli luminoşi şi fără semne de iritație meningeală.

Investigațiile paraclinice la internare au decelat prezența acidozei metabolice $\mathrm{pH}=7,28, \mathrm{~EB}=-9,4$ $\mathrm{mmol} / \mathrm{l}, \mathrm{HCO} 3=14,2 \mathrm{mmol} / \mathrm{l}$, lactat $=3,5 \mathrm{mmol} / 1$, probele funcționale renale au evidenţiat o valoare crescută a creatininei sangvine de $1,57 \mathrm{mg} / \mathrm{dl}$, iar probele hepatice şi hemoleucograma au fost în limite normale. Se efectuează ecografia abdominală, ce a decelat rinichi de dimensiuni crescute, cu dilataţii pielocaliceale şi importantă ștergere a diferenţierii corticomedulare.

S-a iniţiat tratament cu perfuzie cu glucoză şi electroliți şi bicarbonat de sodiu $8,4 \%$ şi s-au monito- rizat funcţiile vitale şi echilibrul acidobazic, glicemia şi funcția hepatică şi renală.

La 24 de ore postadmisie, pacienta asociază alterarea statusului mental şi somnolenţă şi paraclinic se evidențiază persistența fenomenelor de retenție azotată: uree $=59 \mathrm{mg} / \mathrm{dl}$, creatinină $=4,06 \mathrm{mg} / \mathrm{dl}$, acestea coroborate cu modificările ecografice. Se ia decizia transferului către secţia Nefrologie a Spitalului Clinic de Urgenta pentru Copii „M.S. Curie“ din Bucureşti în vederea iniţierii terapiei de epurare extrarenală hemodializă. Rezultatele investigațiilor de laborator în dinamică sunt prezentate în tabelul 1 .

TABEL 1. Datele paraclinice în evoluție

\begin{tabular}{|c|c|c|c|}
\hline & $\begin{array}{c}\text { Valorile } \\
\text { pacientului } \\
\text { la internare }\end{array}$ & $\begin{array}{c}\text { Valorile } \\
\text { pacientului } \\
\text { la } 24 \mathrm{~h} \\
\end{array}$ & $\begin{array}{c}\text { Valori } \\
\text { normale }\end{array}$ \\
\hline $\mathrm{pH}$ & 7,28 & 7,19 & $\begin{array}{l}7,35- \\
7,45 \\
\end{array}$ \\
\hline Exces de baze (mmol/l) & $-9,4$ & $-11,4$ & $-3-+3$ \\
\hline Bicarbonat $(\mathrm{mmol} / \mathrm{l})$ & 14,2 & 16 & $18-23$ \\
\hline Lactat (mmol/l) & 3,5 & 5,5 & $0,5-1,5$ \\
\hline $\operatorname{ALT}(U / I)$ & 19 & 20 & $5-34$ \\
\hline AST (U/I) & 20 & 21 & $0-31$ \\
\hline Uree (mg/dl) & 25 & 59 & $17-43$ \\
\hline Creatinină (mg/dl & 1,57 & 4,06 & $0,65-1,1$ \\
\hline Glicemie (mg/dl) & 95 & 79 & $70-105$ \\
\hline Sodiu (mmol/l) & 145 & 136 & $136-146$ \\
\hline Potasiu (mmol/l) & 4,12 & 4,09 & $3,4-4,5$ \\
\hline Clor (mmol/l) & 103 & 96 & $98-106$ \\
\hline Proteine totale $(\mathrm{g} / \mathrm{dl})$ & 7,78 & 6,81 & $6,6-8,7$ \\
\hline Hemoglobină (g/dl) & 11,2 & 10,6 & $12-15$ \\
\hline Trombocite (/103/ul) & 229.000 & 202.000 & $\begin{array}{c}150,0- \\
400,0 \\
\end{array}$ \\
\hline Număr leucocite $\left(/ 10^{3} / \mathrm{ul}\right)$ & 24.100 & 12.260 & $4,8-10,8$ \\
\hline
\end{tabular}

ALT - alanin aminotransferază, AST - aspartat aminotransferază

După internarea în secția Nefrologie a Spitalului Clinic de Urgenţă pentru Copii „M.S. Curie“ din Bucureşti, se montează un cateter venos central pe vena jugulară dreaptă şi se iniţiază prima şedinţă de hemodializă. La 48 de ore după inițierea hemodializei, evoluția este favorabilă, cu normalizarea funcției renale şi echilibrului acido-bazic. În tabelul 2 sunt prezentate valorile în dinamică ale investigațiilor paraclinice după inițierea hemodializei.

TABEL 2. Răspunsul la hemodializă

\begin{tabular}{|l|c|c|c|c|}
\hline Parametri & $\begin{array}{c}\text { După } \\
\text { ședința de } \\
\text { hemo- } \\
\text { dializă I }\end{array}$ & $\begin{array}{c}\text { Înainte de } \\
\text { ședința } \\
\text { hemo- } \\
\text { dializă II }\end{array}$ & $\begin{array}{c}\text { După } \\
\text { ședința } \\
\text { de hemo- } \\
\text { dializă II }\end{array}$ & $\begin{array}{c}\text { Valori de } \\
\text { referință }\end{array}$ \\
\hline $\mathrm{pH}$ & 7,31 & 7,32 & 7,41 & $\begin{array}{c}7,35- \\
7,45\end{array}$ \\
\hline $\begin{array}{l}\text { Exces de baze } \\
\text { (mmol/l) }\end{array}$ & 4,4 & 3 & 2.2 & $-3-+3$ \\
\hline
\end{tabular}




\begin{tabular}{|l|c|c|c|c|}
\hline \multicolumn{1}{|c|}{ Parametri } & $\begin{array}{c}\text { După } \\
\text { ședința de } \\
\text { hemo- } \\
\text { dializă I }\end{array}$ & $\begin{array}{c}\text { Înainte de } \\
\text { sedința } \\
\text { hemo- } \\
\text { dializă II }\end{array}$ & $\begin{array}{c}\text { După } \\
\text { sedința } \\
\text { de hemo- } \\
\text { dializă II }\end{array}$ & $\begin{array}{c}\text { Valori de } \\
\text { referință }\end{array}$ \\
\hline $\begin{array}{l}\text { Bicarbonat } \\
\text { (mmol/l) }\end{array}$ & 26,2 & 24 & 23 & $18-23$ \\
\hline Lactat (mmol/l) & 4 & 2,2 & 1 & 0,7 \\
\hline Creatinină (mg/dl) & 1,88 & 1,4 & 0,7 & $0,65-1,1$ \\
\hline Uree (mg/dl) & 22 & & 20 & $17-43$ \\
\hline $\begin{array}{l}\text { Anion gap } \\
\text { (mEq/l) }\end{array}$ & 16,9 & & 20 & $3-11$ \\
\hline
\end{tabular}

La 9 zile după ingestia medicamentoasă, s-a externat din secția Nefrologie a spitalului „M.S. Curie“ cu stare generală bună, afebrilă, echilibrată respirator, $\mathrm{TA}=101 / 63 \mathrm{mmHg}, \mathrm{AV}=85 \mathrm{bpm}$, abdomen suplu, mobil cu respirația, nedureros spontan şi la palpare, diureză prezentă. Paraclinic, se evidenţiază funcție renală în limite normale: uree $=45 \mathrm{mg} / \mathrm{dl}$, creatinină $=$ $0,61 \mathrm{mg} / \mathrm{dl}, \mathrm{pH}=7,41, \mathrm{~EB}=0,2 \mathrm{mmol} / 1, \mathrm{HCO} 3=20$ $\mathrm{mmol} / \mathrm{l}$, fără acuze, cu recomandarea de a efectua o evaluare psihologică și psihiatrică.

\section{DISCUȚII}

Am prezentat cazul unei intoxicații acute severe cu metformin la o adolescentă, dată fiind creșterea frecvenței acestei etiologii în rândul populației pediatrice.

În literatură sunt descrise puţine cazuri de intoxicație cu metformin la copii, primul caz a fost raportat de Lacher şi colab.: o adolescentă de 15 ani cu ingestie în scop suicidar de aproximativ $38,25 \mathrm{~g}$ de metformin și care în evoluție a dezvoltat insuficiență renală şi acidoză lactică (6). Un alt studiu multricentric analizează evoluția a 37 de cazuri de copii intoxicați cu metformin cu doze variind între $250 \mathrm{mg}$ şi 16,5 g. Niciunul dintre acești copii nu a prezentat hipoglicemie sau acidoză lactică în evoluție (7). Cazurile de intoxicație acută cu metformin ce asociază acidoză lactică sunt rare, dar cu mortalitate crescută în ciuda evoluției mijloacelor terapeutice (8). Acidoza lactică asociată intoxicației cu metformin este o acidoză metabolică cu gap anionic mare. Există două categorii de acidoză lactică, conform clasificării CohenWoods: tip A, ce apare asociată hipoperfuziei tisulare, şi tip B, ce apare în absența hipoperfuziei tisulare. Dell'aglio şi colab. au raportat cazul unui pacient ce a ingerat aproximativ 75-100 g de metformin, cea mai mare doză de metformin ingerată prezentată în literatură, care a dezvoltat acidoză lactică severă cu valori de pH de 6,59 și valoarea lactatului de $40 \mathrm{mmol} / 1$, dar care, în urma iniţierii dializei renale, s-a recuperat complet fără sechele (9).
Semnele și simptomele asociate intoxicației acute cu metformin sunt nespecifice şi includ: anorexie, greață, vărsături, dureri abdominale, letargie, somnolență şi tahipnee. În evoluție pot să apară complicații precum hipotensiune, hipoglicemie, pancreatită, hipotermie, acidoză lactică, insuficiență renală acută, comă și stop cardiac (3). Conform studiilor de specialitate, nu există o corelație între doza de metformin și valoarea lactatului și evoluția severității cazului (10). Cazul nostru s-a prezentat cu simptome gastrointestinale, alterarea statusului neurologic şi acidoză lactică şi a evoluat către insuficiență renală acută. Încă de la internare, valorile pH-ului, bicarbonatului, excesului de baze şi lactatului au indicat prezența acidozei lactice. În evoluție, urmărirea în dinamică a funcției renale a relevat creșteri ale valorilor ureei și creatininei ce au impus măsuri terapeutice de epurare extrarenală.

Tratamentul intoxicaţiei acute cu metformin este în principal suportiv: se impun măsuri de decontaminare gastrică prin administrarea de cărbune activat în vederea limitării absorbției la nivel intestinal şi corectarea tulburărilor hidroelectrolitice. Administrarea bicarbonatului de sodiu poate o fi o alternativă terapeutică care poate corecta dezechilibrele acido-bazice, dar complicațiile de tipul devierea la stânga a curbei de disociere a oxihemoglobinei, hipernatremie, alcaloză metabolică de rebound, dezechilibre de tip hiper/ hipopotasemie şi hipo/hipercalcemie şi vasodilatație reflexă pot impune prudență în utilizarea sa (11).

Eșecul tratamentului utilizând mijloace conservatoare impune iniţierea măsurilor de supleere renală. De primă intenție se recomandă utilizarea hemodializei, ale cărei beneficii sunt corectarea acidozei refractare, corectarea valorilor lactatului, piruvatului, corpilor cetonici şi tratament suportiv al uremiei (12). Ghidul actual elaborat de grupul de experți EXTRIP recomandă iniţierea măsurilor de epurare extracorporeală după cum urmează: valori ale lactatului mai mari de $20 \mathrm{mmol} / 1, \mathrm{pH} \leq 7$, semne de șoc, alterarea statusului neurologic şi eșecul terapiei suportive. Se recomandă ca aceste măsuri de terapie extracorporeală să fie menținute până se ajunge la o valoare a lactatului mai mică de $3 \mathrm{mmol} / \mathrm{l}, \mathrm{pH}$ cu valoare de 7,35 , iar ca tehnică de terapie de epurare extrarenală este recomandată utilizarea hemodializei intermitente cu posibilitatea utilizării tehnicilor de dializă continuă dacă hemodializa nu se poate efectua (13).

Proprietățile farmacocinetice ale metforminului contribuie la capacitatea sa de a fi eliminat prin tehnici de dializă, cu precizarea că beneficiul maxim al instituirii acestei terapii apare cu cât este mai rapid instituită, dat fiind volumul său de distribuție mare (14). Sunt studii care pledează pentru terapii continue 
de dializă în cazul intoxicațiilor cu metfomin datorită modelului bicompartimental al distribuției sale şi au dovedit eliminarea prin dializă a metforminului întrun procent de $60 \%$ conform valorilor dozate pre şi postiniţiere a terapiei de epurare extrarenală (15).

În cazul pacientei noastre, încă de la debutul simptomatologiei, a fost iniţiat tratamentul prin administrarea de cărbune activat pentru a limita absorbția metforminului și a unei perfuzii endovenoase în scopul corectării deshidratării. Pe parcursul internării în clinica de toxicologie şi terapie intensivă, au fost administrate bicarbonat de sodiu și perfuzii cu glucoză şi electroliți care nu au dus la normalizarea valorilor echilibrului acido-bazic şi a lactatului, iar evoluția pacientei a fost către dezvoltarea unei insuficiențe renale acute, aspect evidențiat de creșterea în dinamică a valorilor ureei şi creatininei şi de modificările ecografice decelate la nivel renal. A fost luată decizia inițierii terapiei de epurare extrarenală şi a fost transferată în secţia de nefrologie a unei alte unităţi spitalicești. După efectuarea primei ședințe de hemodializă, au fost repetate investigațiile paraclinice în vederea obținerii unui bilanț al funcției renale şi echilibrului acido-bazic. Se constată mentinerea unor valori crescute ale creatininei și persistența acidozei lactice, valori ce impun efectuarea unei a două ședinţe de hemodilază. În dinamică, reevaluarea parametrilor biochimici a demonstrat normalizarea funcției renale şi remiterea acidozei lactice, ceea ce a condus la decizia

\section{BIBLIOGRAFIE}

1. Ulmeanu $C$, Nițescu V, Ulmeanu A. Intoxicațiile acute la copil și adolescent. Oltenița: Tridona, 2015.

2. Bailey CJ, Turner RC. Metformin. N Engl J Med. 1996 Feb 29;334(9):574-9.

3. Spiller HA, Quadrani DA. Toxic effects from metformin exposure. Ann Pharmacother. 2004;38(5):776-80.

4. Chu CK, Chang YT, Lee BJ, Hu SY, Hu WH, Yang DY. Metforminassociated Lactic Acidosis and Acute Renal Failure in a Type 2 Diabetic Patient. J Chin Med Assoc. 2003;66(8):505-8.

5. Luft FC. Lactic acidosis update for critical care clinicians. J Am Soc Nephrol. 2001;12(Suppl 17):S15-9.

6. Lacher M, Hermanns-Clausen M, Haeffner K, Brandis M., Pohl M. Severe Metformin Intoxication With Lactic Acidosis in an Adolescent. Eur J Pediatr. 2005;164(6):362-5.

7. Spiller HA, Weber JA, Winter ML, Klein-Schwartz W, Hofman M, Gorman SE et al. Multicenter Case Series of Pediatric Metformin Ingestion. Ann Pharmacother. 2000;34(12):1385-8.

8. Peters N, Jay N, Barraud D, Cravoisy A, Nace L et al. Metformin-associated lactic acidosis in an intensive care unit. Crit Care. 2008; 12(6):R149. sistării ședințelor de hemodializă. Odată inițiată hemodializa în dinamică, s-a obținut normalizarea indicatorilor funcției renale cu ,restitutio ad integrum“ a stării de sănătate.

Particularitatea acestui caz este reprezentată de evoluţia cu alterarea statusului neurologic, asociată cu insuficiență renală acută, ce a impus inițierea hemodializei. Așadar, în cazul intoxicației acute cu metformin, se impune o monitorizare în dinamică a funcției renale ca urmare a posibilităţii evoluției către insuficiență renală acută.

\section{CONCLUZII}

Intoxicația acută cu metformin poate avea o evoluție gravă, putând conduce către deces dacă nu este recunoscută, monitorizată și tratată cât mai rapid. Simptomele asociate intoxicației $\mathrm{cu}$ metformin sunt nespecifice, cu predominanța simptomelor gastrointestinale, cu posibilitatea apariției semnelor neurologice şi a disfuncției multiorgan. Evoluția către acidoză lactică severă a intoxicației cu metformin impune instituirea rapidă a măsurilor terapeutice suportive sau de epurare extrarenală din cauza potențialului letal.

\section{Menţiune}

Ambii autorii au contribuit în egală măsură la elaborarea acestui articol.

Conflict of interest: none declared Financial support: none declared

9. Dell'Aglio DM, Perino LJ, Todino JD, Algren DA, Morgan BW. Metformin overdose with a resultant serum $\mathrm{pH}$ of 6.59 : Survival without sequalae. J Emerg Med. 2010;39(1):e77-e80.

10. Manini AF, Kumar A, Olsen D, Vlahov D, Hoffman RS. Utility of Serum Lactate to Predict Drug-Overdose Fatality. Clin Toxicol (Phila). 2010;48(7):730-6.

11. Ryder RE. The Danger of High Dose Sodium Bicarbonate in Biguanide-Induced Lactic Acidosis: The Theory, the Practice and Alternative Therapies. Br J Clin Pract. 1987;41(5):730-7.

12. Barrueto F, Meggs WJ, Barchman MJ. Clearance of Metformin by Hemofiltration in Overdose. J Toxicol Clin Toxicol. 2002;40(2):177-80.

13. Calello DP, Liu KD, Wiegand TJ et al. Extracorporeal Treatment for Metformin Poisoning: Systematic Review and Recommendations From the Extracorporeal Treatments in Poisoning Workgroup. Crit Care Med. 2015;43(8):1716-30.

14. Guo PYF, Storsley LJ, Finkle SN. Severe Lactic Acidosis Treated With Prolonged Hemodialysis: Recovery After Massive Overdoses of Metformin. Semin Dial. 2006;19(1):80-3.

15. Lalau JD, Andrejak M, Morinière $P$ et al. Hemodialysis in the Treatment of Lactic Acidosis in Diabetics Treated by Metformin: A Study of Metformin Elimination. Int J Clin Pharmacol Ther Toxicol. 1989;27(6):285-8. 